\title{
Impediments of Activating E-Learning in Higher Education Institutions in Saudi Arabia
}

\author{
Case Study: Ar-Rass College of Science and Arts, Qassim University
}

\author{
Ashraf M. H. Abdel Gawad \\ Department of Computer Science \\ Faculty of Science and Arts Qassim University, \\ Saudi Arabia
}

\author{
Khalefah A. K. Al-Masaud, \\ Department of History \\ Faculty of Arabic Language and Social Studies Qassim \\ University, Saudi Arabia
}

\begin{abstract}
This paper presents the real reasons which constraint the application of the E-learning in higher education institutions in Saudi Arabia (Case study: Qassim University)and some suggested solutions. A questionnaire has been designed for the study include 48 paragraphs, divided into 5 parts, the first include the principle information, the second define how the technology can be used in the E-learning, the third deals with how to support the E-learning idea, the fourth part, asking the difficulties and challenges that face the application of E-learning, the fifth items asking to provide suggestion for solving the problem. The study has $\mathbf{1 0 0}$ samples for faculty members and undergraduate students in Ar-Rass college of Science and Arts, male Departments at Qassim University. The study indicates that the main factors that obstruct the E-learning is the financial support from saving advanced $\mathrm{PC}$ 's, labs, and establishing strong computer network, adding to the weakness of some faculty members and student to English language. The study focused in the suggested solution for the problem by applying the Electronic subjects, and imposes the whole faculty members to prepare at least one course in Electronic form.
\end{abstract}

Keywords-E-Learning; Internet; curriculum; Saudi Arabia Universities; cultural aspects

\section{INTRODUCTION}

Due to penetration of advanced technology, computer networks, and communication technology in all sectors of life makes the applications of E-learning much more easier than before[1-2].

E-learning is considered one of the distance learning forms, and can be defined as a method of using advanced technologies in computer science, such as network, software, multimedia, electronic library, international network (internet), and multimedia. The important is to deliver the information using easiest way in a short time i.e. saving time and effort. As a result of rapid advanced in information technologies and its effect in all aspects of life, the university education must be more responsive for these dramatic changes and rapid development. Due to the fact that the production of the university education is considered an input and work items in different economic sectors, the E- learning need a wellestablished infra-structure of a computer networks, so that the institutions think about the cost which can sure the success of E-learning process [3].
E-learning introduces a new form of education and getting knowledge around the world. It can help those whom they live in a remote area to continue their university study by application of advanced in technology in computer networks [4].

E-Learning has amazing prospects for the most of the development countries. For successful deployment of eLearning as a modern teaching method, the readiness of both quantitatively and qualitatively must be measured [5-6].

E-Learning enables the universities and institutions to train their geographically scattered workforce and make them eligible with the dynamic knowledge and skill demands with greater efficiency but at less cost [7-8].

This paper deals with the Impediments of Activating ELearning in Higher Education Institutions in Saudi Arabia, and how we can overcome the difficulties face the application of E-learning. This can be obtained by a questionnaire filled by student and faculty members in 9 departments at Ar-Rass College of Science and Arts, Qassim University, Saudi Arabia.

\section{E-LEARNING DEFINITIONS}

It is well known that the E-learning have many definitions, a few of them will be presented here to extract some understanding [9].

1) Tom Kelly, Cisco: "E-learning is about information, communication, education and training. Regardless of how trainers categorize training and education, the learner only wants the skills and knowledge to do a better job or to answer the next question from a customer."

2) "E-learning provides the potential to provide the right information to the right people at the right times and places using the right medium.

3) "Brandon Hall: “...instruction that is delivered electronically, in part or wholly via a Web browser, (...) through the Internet or an intranet, or through multimedia platforms such CD-ROM or DVD.” Brandon Hall argues that, as the technology improves, e-learning has been identified primarily with using the web, or an intranet's web. Increasingly - as higher bandwidth has become more accessible - it has been identified primarily with using the 
Web, or an intranet's web, forcing the visual environment and interactive nature of the web on the learning environment.

4) Learning Circuits: "E-learning covers a wide set of applications and processes such as web-based learning, computer-based learning, virtual classrooms and digital collaboration. It includes the delivery of content via the Internet, intranet/extranet, audio and videotape, satellite broadcast, interactive TV and CD-ROM."

5) Rosenberg: "E-learning refers to the use of Internet technologies to deliver a broad array of solutions that enhance knowledge and performance." Rosenberg claims that elearning is based on three fundamental criteria:

\section{BENEFITS AND DisADVANTAGES}

The learning modalities have their strengths and weaknesses. The list of benefits and disadvantages of elearning can be summarized as the following[10]:

a) Benefits of E-Learning

1) Reduced cost. The total cost can be reduced through reducing the instructor costs, travel expenses, room rentals, lodging and meals. The time required for attending the class could be used for other duties.

2) Efficient. The e-learning is efficiently uses resources to train many people. In synchronous class one instructor can be sufficient for many classes in many locations in the same time. Globally consistent. E-learning provides a global solution to the employees whom they work away from the home office.

3) Scalable. E-learning solutions scale more easily than traditional classroom training. Universal access to experts. Asynchronous e-learning overcome the problem of communications with the instructor. E-learning provides cross-border access and/or exposure to expert knowledge and top instructors.

4) Reduces/eliminates travel. E-learning eliminates the travel expenses.

5) Trackable. E-learning solutions can provide tracking mechanisms that record attendance, completion and time spent on specific training modules.

6) Convenient. Asynchronous e-learning solutions allow a student to learn based on their personnel circumstances. Synchronous e-learning allows students in different locations to attend classes morning or evening.

\section{b) Disadvantages}

1) Initial investment: The costs to establish an e-learning infrastructure can be hit the ledger in Year One, although the e-learning program may have a lifespan that lasts several years.

2) Inappropriate content: The content must match the community requirements. Complex issues that require handson learning may not fit the model.

3) Technology issues: As bandwidth and hardware costs continue to decrease, e-learning becomes more relevant as a learning solution. Remote areas with limited bandwidth may not be able to realize the benefits of e-learning.

4) Diminished personal interaction: E-learning limits personal interactions between the instructor and students. The forms of communication are dramatically limited with elearning. Instructors may find it difficult to determine the level of the students of the subject matter.

5) Employee acceptance: Due to rapid development in communications and technology, more employees became familiar with it, and the acceptance for e-learning grows. Some employees particularly may feel uncomfortable with elearning. Cultural issues may also inhibit the use of technology for e-learning.

6) Motivation: E-learning, particularly asynchronous training, requires students to take the initiative to start and complete the training. Some students may not be motivated to allocate the time to learn.

\section{The STudy Questions:}

The study focus on determining the reasons that prevent application of E-learning in Saudi Arabia Higher institutes, and how can overcome the difficulties to spread the Elearning. The problem formulations can be determining through the following questions:

1) Is the current technology is useful in applying Elearning?

2) What are the motivations that support the idea of using E-learning?

3) What are the difficulties that face applying $E$ learning?

4) What are the suggested solutions to this problem?

\section{IMPORTANCE OF THE STUDY}

This study aims to find out the difficulties and constraints that face the E-learning in the university community from the student and faculty members' point of view. Also, how to overcome the problem of applying the E-learning in a wide range, regarding the need of community, to this type of education.

\section{OBJeCt OF THE STUdy}

The study aims to the following points:

1) Find out the reasons that obstruct the application of E-learning in the higher education institutes in Saudi Arabia.

2) The feasibility of the current technology in supporting the E-learning.

3) Find the motivation that can support the E-learning.

4) Defining the solution of the problem and how to apply it.

\section{Limitations of the Study:}

The study has been developed within the following limits:

1) The factors that effect in e-learning applications in Higher Institutions.

2) Sample from the undergraduate student and Faculty members. 
3) Defining the problem through 4 main factors.

4) The questionnaire is applied in the first semester of the academic year 1432/1433 $\mathrm{H}$.

\section{ANALYSIS OF THE STUDY:}

The questionnaire has been distributed to all departments in the college. The distribution process considering the faculty members belongs to the science departments, the faculty members belongs to Arts department, the student belongs to science departments, and the student belongs to Arts Departments. A table 1 through 4 indicates the results of the questionnaire.

From the results of the study we can summarize the following points:

1) The use of internet chat relay group, E-mail, discussion group and computer based instructions are the most suitable tools that can supporting the use of E-learning.

2) The motivations that support the E-learning process such as provide the chance for completing the university study, helping the student in studying their subjects with less effort, and helping the student to develop their own skills.

3) The Impediments that face the applications of Elearning can be summarized from the study as the following points:

a) Some of the students and some faculty members survive from the poor culture of using PCs.

b) Poor infrastructure for the computer networks.

c) The computer labs in the college is not sufficient to handle the process. English.

d) Some of the faculty members and student have poor

e) There is not enough training program to develop the culture of E-learning.

1) The following are the suggested points to overcome the applying the E-learning process at the college:

a) Providing training program to the student to develop their ability to use the computer.

b) Applying the E-subjects.

c) The faculty members must form at least one of their subject in one of the know E-Form.

d) Providing the internet to the office of the faculty members with advanced PCs.

e) Encourage the faculty members to apply E-learning.

f) Attract the faculty members from those are professional in applying E-learning.

g) Introduce the E-test for some subjects.

h) Establish an individual budget to buy computer programs that help in applying E-learning.
TABLE I. SECONd PARAgraph: Do You Think The Use OF The FOLLOWING TECHNOLOGIES IN THE PROCESS OF E-LEARNING IS USEFUl?

\begin{tabular}{|l|l|l|l|l|l|}
\hline & $\begin{array}{l}\text { Totally } \\
\text { agree }\end{array}$ & Agree & Neutral & disagree & $\begin{array}{l}\text { Totally } \\
\text { disagree }\end{array}$ \\
\hline 1 & $100 \%$ & & & & \\
\hline 2 & $100 \%$ & & & & \\
\hline 3 & $100 \%$ & & & & \\
\hline 4 & & $84 \%$ & $16 \%$ & & \\
\hline 5 & & $80 \%$ & $20 \%$ & & \\
\hline 6 & & & $60 \%$ & $40 \%$ & \\
\hline 7 & & & $56 \%$ & $44 \%$ & \\
\hline 8 & & & $52 \%$ & $36 \%$ & $12 \%$ \\
\hline
\end{tabular}

TABLE II. Third PARAgraPh : MOtIVATIONS THAT CAN SUPPORT THE IDEA OF USING E-LEARNING

\begin{tabular}{|l|l|l|l|l|l|}
\hline & $\begin{array}{l}\text { Totally } \\
\text { agree }\end{array}$ & Agree & Neutral & disagree & $\begin{array}{l}\text { Totally } \\
\text { disagree }\end{array}$ \\
\hline 1 & $80 \%$ & $20 \%$ & & & \\
\hline 2 & $88 \%$ & $12 \%$ & & & \\
\hline 3 & $40 \%$ & $60 \%$ & & & \\
\hline 4 & $76 \%$ & $24 \%$ & & & \\
\hline 5 & $44 \%$ & $56 \%$ & & & \\
\hline 6 & $56 \%$ & $44 \%$ & & & \\
\hline 7 & $64 \%$ & $36 \%$ & & & \\
\hline 8 & $72 \%$ & $28 \%$ & & & \\
\hline 9 & $88 \%$ & $12 \%$ & & & \\
\hline 10 & $84 \%$ & $16 \%$ & & & \\
\hline
\end{tabular}

TABLE III. FOURTH PARAGRAPH: DIFFICULTIES AND CHALLENGES FACING THE APPLICATION OF E-LEARNING

\begin{tabular}{|l|l|l|l|l|l|}
\hline & $\begin{array}{l}\text { Totally } \\
\text { agree }\end{array}$ & Agree & Neutral & disagree & $\begin{array}{l}\text { Totally } \\
\text { disagree }\end{array}$ \\
\hline 1 & & $80 \%$ & $12 \%$ & $8 \%$ & \\
\hline 2 & & $76 \%$ & & & \\
\hline 3 & & & $8 \%$ & $16 \%$ & $76 \%$ \\
\hline 4 & & & $12 \%$ & $72 \%$ & $16 \%$ \\
\hline 5 & & & $8 \%$ & $84 \%$ & $8 \%$ \\
\hline 6 & & & & $88 \%$ & $12 \%$ \\
\hline 7 & & $84 \%$ & $8 \%$ & $8 \%$ & \\
\hline 8 & & & $4 \%$ & $8 \%$ & $88 \%$ \\
\hline 9 & & & $8 \%$ & $84 \%$ & $8 \%$ \\
\hline 10 & $8 \%$ & $88 \%$ & $4 \%$ & & \\
\hline 11 & & & $8 \%$ & $80 \%$ & $12 \%$ \\
\hline 12 & $4 \%$ & $84 \%$ & $12 \%$ & & \\
\hline 13 & & & $4 \%$ & $92 \%$ & $4 \%$ \\
\hline 14 & $80 \%$ & $8 \%$ & $12 \%$ & & \\
\hline 15 & & & $8 \%$ & $80 \%$ & $12 \%$ \\
\hline 16 & & & $4 \%$ & $4 \%$ & $92 \%$ \\
\hline 17 & & & $4 \%$ & & $96 \%$ \\
\hline 18 & $8 \%$ & $84 \%$ & & $4 \%$ & \\
\hline 19 & $4 \%$ & $88 \%$ & $8 \%$ & & \\
\hline 20 & & & & $92 \%$ & $8 \%$ \\
\hline & & & & \\
\hline
\end{tabular}


TABLE IV. FIFTH PARAGRAPH: PROPOSALS THAT CAN CONTRIBUTE TO OVERCOMING THE PROBLEMS OF APPLICATION OF E-LEARNING

\begin{tabular}{|l|l|l|l|l|l|}
\hline & $\begin{array}{l}\text { Totally } \\
\text { agree }\end{array}$ & Agree & Neutral & disagree & $\begin{array}{l}\text { Totally } \\
\text { disagree }\end{array}$ \\
\hline 1 & $4 \%$ & $92 \%$ & $4 \%$ & & \\
\hline 2 & $4 \%$ & $88 \%$ & $8 \%$ & & \\
\hline 3 & $12 \%$ & $84 \%$ & $4 \%$ & & \\
\hline 4 & $4 \%$ & $92 \%$ & $4 \%$ & & \\
\hline 5 & $4 \%$ & $96 \%$ & & & \\
\hline 6 & $8 \%$ & $92 \%$ & & & \\
\hline 7 & & $96 \%$ & $4 \%$ & & \\
\hline 8 & $4 \%$ & $96 \%$ & & & \\
\hline 9 & & $96 \%$ & $4 \%$ & & \\
\hline 10 & $8 \%$ & $88 \%$ & $4 \%$ & & \\
\hline
\end{tabular}

\section{RESULTS AND RECOMMENDATIONS}

The study indicated that there are some tools can help in applying the E-learning such as E-mail, internet chat replay group, and computer based instructions. Also, the motivation that can support the idea of E-learning is that helping those whom lives a way from the institutions to complete their university study and develop the student skills. The E-learning provided some services for the student and the faculty members. The major factors that resist the application of Elearning are summarized as the following points:

- Poor culture of using PCs.

- The infrastructures for the computer networks are not well structured.

- The computer labs need to be provided with advanced computer systems.

- low level of English language for Some of the faculty members and students.

- There is not enough training program to develop the culture of E-learning.

In order to remove the resistance of applying E-learning, there are some points must be considered, such as establishing a training program for faculty members and students, applying E-Test for a certain number of subjects, providing the internet service to the whole buildings in the college. The results of the study could be useful for other countries with the same circumstances and culture.

\section{CONCLusions}

The paper presents and analysis of factors affecting, the application of E-learning at Qassim university (Ar-Rass College of Science and Arts, Qassim University). Also, presents how can face the problem and improve the culture of e-learning in the university community. The study propose the factors that help in applying e-learning such as E-mail groups, internet chat groups and computer based instructions. Also, applying the E-courses for few subject will force both students and faculty members to raise their ability to deal with Elearning. The difficulties that face applying E-learning is discussed and presented. The result indicate the importance of finding a good media for applying E-learning such as establish adavanced computer laps, establish a training programs to train and the students and faculty members for using Elearning.

\section{Suggested Future Work}

The work can be applied for females department to judge if the same difficulties or another factors rather that found in males department. Different factors could be considered at the questionnaire. Reduce the factors of questionnaire in order to determine exactly the difficulties and how to face it within simple applicable procedures.

\section{REFERENCES}

[1] Sarah El-Gamal, and Rasha Abd El Aziz, " The Perception of Students Regarding E- Learning Implementation in Egyptian Universities- The Case of Arab Academy for Science and Technology" The $3^{\text {rd }}$ Int. Conf. on Mobile, Hybrid, and On-line Learning, 2011, pp. 1-5.

[2] Abd El Aziz, R. (2009), ATM Location and Usage in Egypt: Social and Technical Perspectives, PhD Thesis, University of the West of England, Brisol, UK.

[3] Wagner, N., Hassanein, K., and Head, M. (2008). Who is responsible for E-Learning Success in Higher Education? A Stakeholders' Analysis. Educational Technology \& Society, 11 (3), 26-36. [Online]. (Accessed: 2 December 2010). Available at: http://www.ifets.info/journals/11_3/3.pdf.

[4] Nagwa El Shenawi, "E-Learning, Challenges and Opportunities: The Case of Egypt" Egypt, 2004.

[5] Chandan Kumar Karmakar, CM Mufassil Wahid, RECOMMENDATIONS FOR BANGLADESH TOWARDS ELEARNING READINESS" Proceedings of the $2^{\text {nd }}$ Int. Conference on eLearning for Knowledge-Based Society, August 4-7, 2005, Bangkok, Thailand.

[6] Spiros Ap. Borotis and Angeliki Poulymenkou.] "E-Learning Readiness Components: Key Issues to Consider Before Adopting e-Learning Interventions" The leading digital library dedicated to education and information technology, Paper Id:11555, found at: http://editlib.org/noaccess/11555.

[7] Rosenberg, M.J. (2000a). e-Learning: Strategies for Delivering Knowledge in the Digital Age: McGraw-Hill.

[8] Rosenberg, M.J. (2000b). The E-Learning Readiness Survey. Retrieved February 2004, from: http://ww.books.mcgrawhill.com/training/elearning/eLearning_Survey.p df

[9] E-learning, A research note by Namahn, it found in: www.namahn.com/resources/.../note-e-learning.pdf

[10] The Value of E-learning, IBM Training, White Paper: found at: http://www.ibm.com/software/lotus/training. 
XI. APPENDix: (Questionnaire USED FOR THE STUdY) Name(OPTION):

NAME(OPTION):

\begin{tabular}{|c|c|c|c|}
\hline \multicolumn{4}{|c|}{ FIRST: BASIC INFORMATION: * PLEASE TICK THE APPROPRIATE BOX THAT APPROPRIATE TO YOUR STATUS. } \\
\hline \multicolumn{2}{|l|}{ 1-GENDER } & \multicolumn{2}{|l|}{ 2- PROFESSION } \\
\hline FEMALE ( & MALE ( & FACULTY MEMBER & STUDENT \\
\hline \multicolumn{2}{|c|}{ 3- ACADEMIC QUALIFICATIONS } & 4- DEPARTMENT & \\
\hline \multirow[t]{2}{*}{ PH.D. ( ） } & \multirow[t]{2}{*}{ M.SC. ( ) } & COMPUTER SCIENCE & PHYSICS \\
\hline & & ISLAMIC STUDY\& QURAAN ( ) & CHEMISTRY \\
\hline \multirow[t]{3}{*}{ B.SC. $(\quad)$} & \multirow[t]{3}{*}{ OTHER ( ） } & ENGLISH LANGUAGE & SpeCial EDUCATION \\
\hline & & ARABIC LANGUAGE $\quad($ & BASIC EDUCATION \\
\hline & & OTHER & \\
\hline \multicolumn{2}{|c|}{$\begin{array}{l}\text { 5- LEVEL OF PROFICIENCY IN DEALING WITH THE } \\
\text { COMPUTER AND APPLIED SOFTWARE }\end{array}$} & \multicolumn{2}{|c|}{ 6- DO YOU USE THE PC IN YOUR WORK (EDUCATION) } \\
\hline BEGINNER $\quad(\quad)$ & GoOD & \multirow[t]{2}{*}{ YES $\quad(\quad)$} & \multirow[t]{2}{*}{ No $(\quad)$} \\
\hline VERY GOOD（） & PROFESSIONAL ( ） & & \\
\hline \multicolumn{2}{|c|}{ 7- Do YOU HAVE PC IN YOUR HOME (OFFICE)? } & \multicolumn{2}{|c|}{ 8- HOW MANY TIMES YOU USE INTERNET? } \\
\hline \multirow[t]{2}{*}{ YES } & \multirow[t]{2}{*}{ No $\quad(\quad)$} & DAILY & ONCE EACH 2 DAYS \\
\hline & & ONCE EACH 3 DAYS & RARELY \\
\hline
\end{tabular}

\begin{tabular}{|c|c|c|c|c|c|c|}
\hline \multicolumn{2}{|c|}{$\begin{array}{l}\text { Second: What do you think the use of the following technologies in the process of e- } \\
\text { learning } \\
* \text { Please tick the appropriate box of the extent of your agreement to these justifications. }\end{array}$} & \multirow[t]{2}{*}{ 育 } & \multirow[t]{2}{*}{ 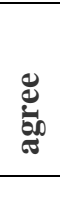 } & \multirow[t]{2}{*}{ 垔 } & \multirow[t]{2}{*}{ 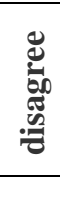 } & \multirow[t]{2}{*}{ 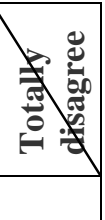 } \\
\hline 1 & Electronic Mail & & & & & \\
\hline 2 & Internet & & & & & \\
\hline 3 & Internet Relay Chat (IRC) & & & & & \\
\hline 4 & Discussion Group & & & & & \\
\hline 5 & Computer Based Instruction & & & & & \\
\hline 6 & Video Conference & & & & & \\
\hline 7 & Virtual Class & & & & & \\
\hline 8 & News Group & & & & & \\
\hline
\end{tabular}


Third: Motivations that can support the idea of using e-learning

* Please tick the appropriate box of the extent of your agreement to these justifications.

\begin{tabular}{|c|c|c|c|c|}
\hline & & & & \\
\hline 1 & Given many opportunities to pursue higher education & & & \\
\hline 2 & Help students to communicate with the college easily & & & \\
\hline 3 & $\begin{array}{l}\text { Help students complete their college education and to overcome the geographical } \\
\text { difficulties. }\end{array}$ & & & \\
\hline 4 & $\begin{array}{l}\text { Make communication between students and faculty members in the process very } \\
\text { easy. }\end{array}$ & & & \\
\hline 5 & Help students to communicate with each other. & & & \\
\hline 6 & Help develop students' skills in dealing with the computer & & & \\
\hline 7 & $\begin{array}{l}\text { Help in the preparation of qualified human resources, which are commensurate } \\
\text { with the quality programs. }\end{array}$ & & & \\
\hline 8 & Help create a competitive environment between the educational institutions & & & \\
\hline 9 & Helps to spread higher education in areas that do not have institutes or colleges. & & & \\
\hline 10 & Help to provide electronic services to students, as well as faculty members. & & & \\
\hline
\end{tabular}

Fourth: Difficulties and challenges facing the application of e-learning * Please tick the appropriate box of the extent of your agreement to these justifications.

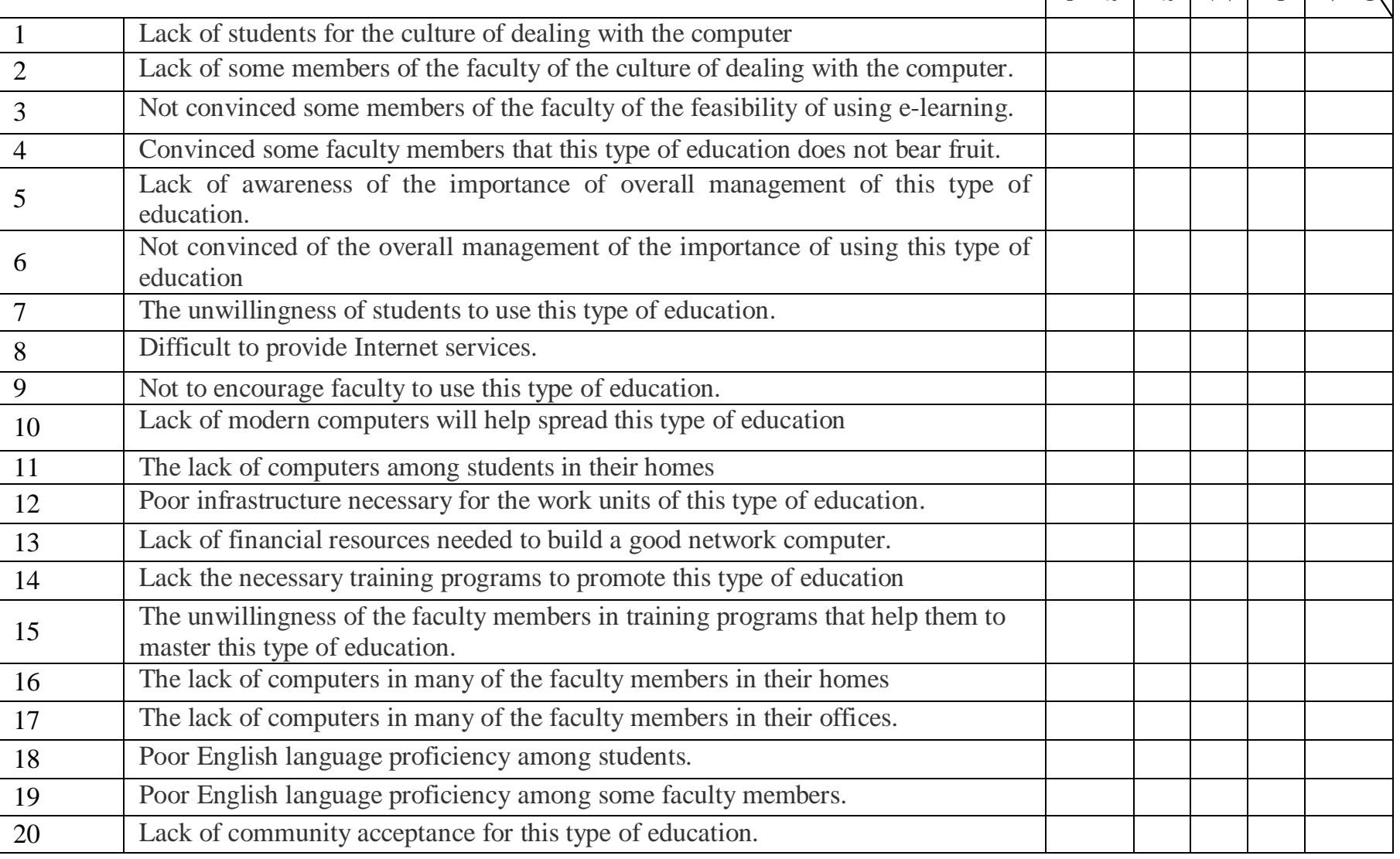




\begin{tabular}{|c|c|c|c|c|c|c|}
\hline \multicolumn{2}{|c|}{$\begin{array}{l}\text { Fifth: Proposals that can contribute to overcoming the problems of application of e- } \\
\text { learning } \\
* \text { Please tick the appropriate box of the extent of your agreement to these justifications. }\end{array}$} & \multirow[t]{2}{*}{ 尝 } & \multirow[t]{2}{*}{ D. } & \multirow[t]{2}{*}{ Z } & \multirow[t]{2}{*}{ 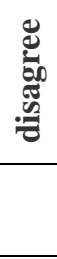 } & \multirow[t]{2}{*}{ 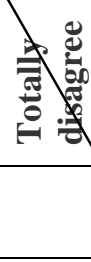 } \\
\hline 1 & $\begin{array}{l}\text { Rehabilitation of the student to deal with the establishment of computer training } \\
\text { programs. }\end{array}$ & & & & & \\
\hline 2 & The application of e-courses effectively. & & & & & \\
\hline 3 & $\begin{array}{l}\text { Establishment of training courses for students and faculty members to enable them } \\
\text { to implement e-learning. }\end{array}$ & & & & & \\
\hline 4 & $\begin{array}{l}\text { Requiring members of the faculty composition of decision-mail at least those that } \\
\text { they teach. }\end{array}$ & & & & & \\
\hline 5 & Provide a computer for each member of the faculty office. & & & & & \\
\hline 6 & Make the internet service accessible within the college. & & & & & \\
\hline 7 & Motivate and encourage faculty members to implement e-learning. & & & & & \\
\hline 8 & Attract qualified human resources to implement this type of education. & & & & & \\
\hline 9 & Introduce of electronic tests on some courses & & & & & \\
\hline 10 & $\begin{array}{l}\text { A separate budget for the purchase of software that contribute to the } \\
\text { implementation of e-learning. }\end{array}$ & & & & & \\
\hline
\end{tabular}

